\title{
DEVELOPING TEACHING OF CONTEXTUAL WRITTEN LANGUAGE SKILL TO STUDENTS WITH DIFFERENT LEARNING STYLES
}

\author{
Fahri Haswani, S.Pd, M.Hum \\ Universitas Negeri Medan
}

\begin{abstract}
This study aimed at developing the teaching of contextual written language skill to students with different learning styles. The design of this research was research and development study. The data were collected by using questionnaires and observation sheet. The subject of the study is the students of English Education Program 2017. The object of the study are the students learning styles in learning reading comprehension and writing skill. The data were analyzed by using Fleming theory. The purpose of conducting this research was find out whether the most dominant learning style in reading comprehension and writing skill and to find out what are the types of student's learning styles which has higher achievement in reading comprehension and writing skill of English Education Program 2017. There were 32 students as the subject of this research. In this case, the researcher collected the data by using learning style questionnaire and observation. The result showed that auditory learning style is the most dominant learning style at the tenth-grade students at English Education Program, the percentage was $71,87 \%$, it means 23 from 32 students prefer to hear than read and move. The second was kinesthetic learning style, the score, 21,88\%, means that only 7 students prefer to move. Then, visual learning style, score 6,25\%, means that 2 from 32 students prefer to read. For the fastest student's in reading comprehension came from auditory students or auditory learners. They get score $69,56 \%$ followed kinesthetic 21,74\%, and visual 8,70\%. After analyzing the data, the researcher designed the teaching strategy included inside and outside classroom activities.
\end{abstract}

Keywords: learning style, contextual written language skill.

\section{INTRODUCTION}

Writing usually perceived as dealing with the language messages in written or printed texts. It is an important skill to be learned because writing is very necessary for students to express sense and give meaning to the readers. Writing is a special skill which must be mastered by university students because most of students' task relate to writing. More over to finish the learning process in a university student must write academic writing such as a thesis.

In English education study program teaching writing is collaborated with reading. The name of this subject is Contextual Written Language Skill. In this subject student learn writing after they have stimulation by reading and comprehending some texts. Writing activities are given to students to support their comprehension in reading. To get good result for students' achievements in reading and writing, the lecturer is suggested to know students' learning styles.

Learning is one of the most important individual process that occurs in education and training programs (Kimble \& Garmezy 1963:2). Learning is a relatively permanent change in a behavioural tendency and is the result of reinforced practice. It means that the behaviour that occurred after certain learning probably settled. Someone's capabilities will not be disappearing but will keep developing even more when someone continues keep practicing. This statement strengths the importance of learning styles in conducting learning of a subject.

There are some learning styles which can be observed to students because the students are created differently. The lecturer should know the types of the students learning style so the lecturers know what the teaching strategy or teaching method will be applied in the teaching learning process in order to get the purpose of the learning.

Based on the explanation above, it is important to educators or the teachers to understand the differences of the students' learning style, so they can implement best practice strategies into their daily activities, curriculum and assessments. The students will get interest and comprehend if the teacher knows the students' learning style. 


\section{DISCUSSION}

Learning styles can be defined, classified, and identified in many different ways. Learning style can also be described as a set of factors, behaviors, and attitudes that facilitate learning for an individual in a given situation. Brown (2000) defines learning styles as the manner in which individuals perceive and process information in learning situations. He argues that learning style preference is one aspect of learning style and refers to the choice of one learning situation or condition over another. Celce-Murcia (20014) defines learning styles as the general approaches for example, global or analytic, auditory or visual that students use in acquiring a new language or in learning any other subject. The manner in which a learner perceives, interacts with, and responds to the learning environment. Learning style is sometimes defined as the characteristics of cognitive, affective, social, and physiological behaviors that serve as relatively stable indicators of how learners perceive, interact with, and respond to the learning environment" (MacKeracher,2004, p. 71).

Students' learning style influenced by some factors, according to Dunn and Dunn (Dunn and Dunn, 1993, in Rita Dunn and Shirley A. Griggs, 2002): Environmental: it likes sound, light, temperature in learning process is very influencing to students' learning. Some students like to learn in a comfortable place or in a quiet place and there is no noisy sound, but other students like to listen the radio while they are reading a book emotionally. It means that the emotion of students such as motivation and learning styles give contribution how they get their goals in learning. Motivation can be the main power driver to attract students. Motivation decided into two, they are extrinsic motivation an intrinsic motivation. Extrinsic motivation is forced motivation to get the high advantage such as reward and punishment. Intrinsic motivation is the inside stimulus of the students, it means that the motivation comes from inside.

The learning styles and motivation also influence the students' habit in learning literacy. Reading comprehension is the process of constructing meaning from text. The goal of all reading instruction is ultimately targeted at helping a reader comprehend text. Reading comprehension involves at least two people the reader and writer. The process of comprehending involves decoding the writer's words and then using background knowledge to construct an approximate understanding of the writer's message.

To improve students' comprehension in reading, writing activity is also needed to be improved. Writing can be used to know how deep students encode a text. If the students can write and elaborate what they read in an essay it can be concluded that they get comprehension and idea. This process is decided as learning a literacy.

Learning is something of which we all have an understanding and in which we have all participated. This participation has been in a very wide range of settings, both formal and informal, ranging from the relative confines of a school classroom, to the wide-open spaces of the countryside or a quiet corner where a chance conversation led to deeper understanding of some topic or another.

Learning styles have been shown in several studies to have influenced the way in which a person learns, comprehends, and produces language. Identifying students' learning styles has been found to be a significant factor in effective instruction and learning quality.

Each student has a type or style of learning on their own. The ability of the students in comprehending the material and lessons depending on their learning style. Learning style is the identity of every person in responding to the learning received. Student's learning style is based on the modalities they have, anyone have a visual learning style, auditory and some that have a kinesthetic learning style. Visual learning style is a way of learning by seeing. Characteristics of visual learning style are associated with visual. A student will be easier to remember if aided by pictures and prefers to read on their own rather than be read by others. Auditory learning style is a style of learning by listening. Characteristics of this model really put the hearing as the primary means to acquire information or knowledge. Students with auditory style usually have the strength in listening. Characteristics of this model really put the hearing as the primary means to acquire information of knowledge. So, this model of learning styles should listen first and then be able to remember and understand the information. While kinesthetic learning style requires that students are concerned touching something that gives information so that he could remember. So, here to find the most dominant learning style, it used questionnaire.

Reading comprehension will help students to understand the text. Leaning has relation to students' learning styles and also reading comprehension. In learning, it is important to know the learning styles of the students, so we must identify the students' tendency toward in learning styles. So it says that both of them have relation. Learning also related to reading. In teaching learning process 
reading is one of the important aspects that should be improved. By reading the students can get more information. In reading it is a must to pay attention with something that we read. It means that the students have to comprehend the reading, especially in reading text, but students still have difficulties to comprehend the text such as, hard to find the main idea of the text, hard to comprehend English word, and so on. These difficulties may be occurs because the teachers could not find the best teaching strategies to provide the material. It will be better if students' learning styles identify that may be help students to more easily in reading comprehension. If teachers provide the material based on learning style of their students it can help the problem.

This research was conducted by research and development study. The data was collected through questionnaires, observations, and Interviews. The explanations are below:

1. Observations

By observing teaching-learning process, the writer can get the data from natural situation. In the observation process, the writer plays role of observer as participant in which the role of the researcher is known by the participants. The instrument of observing the respondents are observation sheet.

2. Questionnaire

The questionnaire is used to know the students' learning styles in learning reading comprehension. The questionnaires will be answered by the students.

After getting the data, the researcher discussed, analyzed and designed the strategies of learning for students with different learning styles. To categorize the students' learning styles, the researcher used learning style analysis as the explanation below.

Learning Style of Visual: Learning style is easy to see or imagine what was discussed. Often see pictures associated with words or feelings, and they understand the information when viewing the scene saw the information in writing or in picture.

Learning Style of Auditory: Express themselves through sound, be it through internal communication with oneself and external with others. When they wanted to write something, these people will hear the sound of what he wrote. When you have met and will talk with someone new, he will do the mental gymnastics about what to say and how to express it.

Learning Style of Kinesthetic: Sensitive to the feelings or emotions and the sensation of touch and movement. When the students with this style are asked to write a word, they loved to write it by moving from one corner to another corner of the class. Kinesthetic students learnt while they involve with a lot of physical engagement and movement.

The researcher found that the type visual learner were 8 students $(32 \%)$, auditory learner were 10 students $(40 \%)$ and kinesthetic learners were 7 students $(28 \%)$. As the result, the auditory learner more dominant than kinesthetic and visual learner of ten students in English language department.

Table 1. Score of Students

Visual Learning Style in Studying Vocabulary

\begin{tabular}{ccc}
\hline No & Initial Name & Score \\
\hline 1 & AC & 6 \\
\hline 2 & AW & 6 \\
\hline 3 & DIN & 6 \\
\hline 4 & PS & 5 \\
\hline 5 & PR & 6 \\
\hline 6 & RRR & 6 \\
\hline & Percentage \\
\hline
\end{tabular}


Table 2 Score of Students

Aural Learning Style in Studying Vocabulary

\begin{tabular}{ccc}
\hline No & Initial Name & Score \\
\hline 1 & AA & 9 \\
\hline 2 & LP & 6 \\
\hline 3 & RA & 11 \\
\hline 4 & ND & 8 \\
\hline 5 & AI & 7 \\
\hline 6 & PMN & 7 \\
\hline 7 & PPT & 6 \\
\hline & Percentage & $18.4 \%$ \\
\hline
\end{tabular}

Table 4.3 Score of Students

Read/ Write Learning Style in Studying Vocabulary

\begin{tabular}{|c|c|c|}
\hline No & Initial Name & Score \\
\hline 1 & ACS & 6 \\
\hline 2 & SM & 6 \\
\hline 3 & PL & 6 \\
\hline 4 & APW & 7 \\
\hline 5 & $\mathrm{DM}$ & 7 \\
\hline 6 & IM & 6 \\
\hline 7 & $\mathrm{MF}$ & 6 \\
\hline 8 & MRO & 7 \\
\hline 9 & MYI & 6 \\
\hline 10 & MBN & 5 \\
\hline 11 & $\mathrm{NK}$ & 8 \\
\hline 12 & PPH & 7 \\
\hline 13 & RYN & 6 \\
\hline 14 & RHB & 6 \\
\hline 15 & RR & 7 \\
\hline 16 & SA & 6 \\
\hline 17 & $\mathrm{HA}$ & 5 \\
\hline 18 & IT & 8 \\
\hline 19 & $\mathrm{OK}$ & 7 \\
\hline 20 & $\mathrm{KL}$ & 6 \\
\hline \multirow[t]{2}{*}{21} & KLM & 8 \\
\hline & Percentage & $55.2 \%$ \\
\hline
\end{tabular}

Table 4.4 Score of Students

Kinesthetic Learning Style in Studying Vocabulary

\begin{tabular}{ccc}
\hline No & Initial Name & Score \\
\hline 1 & AS & 7 \\
\hline 2 & TS & 6 \\
\hline 3 & RDH & 7 \\
\hline 4 & JHB & 6 \\
\hline & Percentage & $10.5 \%$ \\
\hline
\end{tabular}




\section{Percentage of Students Vark Learning Style}

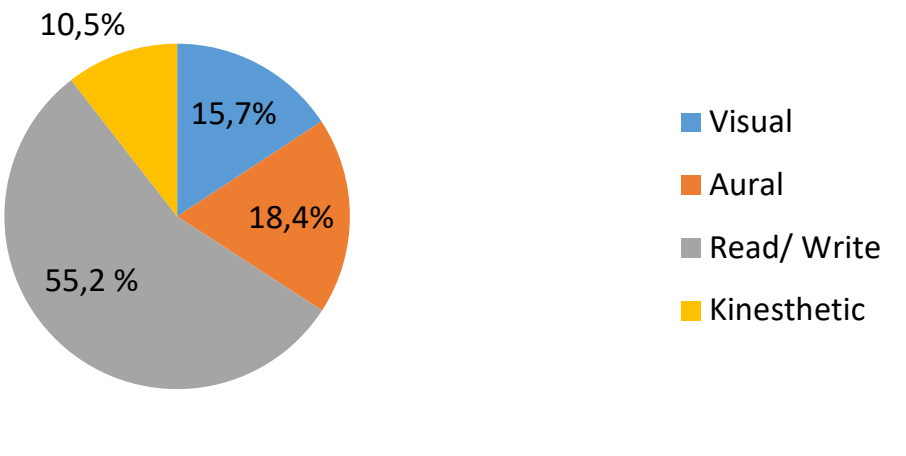

After observing the students' learning styles, the researcher designed learning strategies to facilitate students style in learning literacy. The learning strategies could be conducted in a classroom and out of a classroom. The strategies which are used will be explained below:

\section{A. Inside Classroom Activities}

1. For the first stage, In the opening learning process students could be asked to do the brain gym. The goal of this activity is to stimulate brain function in preparing students to learn. Students who have kinesthetic style in learning learn to rely too much on one cerebral hemisphere of the brain alone, instead of two sides together, placing unnecessary and stressful demands. For students who have visual learning style demonstration from the movement of the brain gym will process their brain to gain and retain information. For students who have auditory style in learning, the music will stimulate in hearing information.

2. The second step, students could be asked to discuss some issues and present the information that they got from some journals related to writing topic.

3. The third step, students conclude a summary of their discussion and make the display on the wall of classroom.

\section{B. Outside Classroom Activities}

Learning outside classroom develops sense of students to care what happen in their environment. The three learning styles deal with this place of learning. Small research could be given as their needs to learn. By interviewing people and making appointment with their research colleagues will accommodate their visual, auditory, and movements (Kinesthetic) in responding what they want to search. After they had data from the research, they could be asked to write essay or research journal to practice their skill in English writing.

\section{CONCLUSIONS}

Based on the analyzing data in the previous chapter, it could be drawn the conclusion of the present study which were designed to suit the objectives the study. This study was obtained tofind out what is the most dominant learning style in reading at the third semester of English Education Program. There are three types of learning styles, visual, auditory and kinesthetic. The conclusion of the present study can be drawn as follows:

1. Auditory learning style is the most dominant learning style at the eleventh-grade students at English Education Program, the percentage was 71,87\%, it means 23 from 32 students prefer to hear than read and move. The second was kinesthetic learning style, score $21,88 \%$, means that 7 
from 32 students prefer to move. Then, visual learning style, the sore, 6,25\%, means that only 2 students prefer to read.The main data gathered through questionnaire and observation.

Auditory learning style was the most dominant learning style, followed kinaesthetic learning style $21,88 \%$ and visual learning style that has the lowest score $6,25 \%$. For the fastest students in reading comprehension came from auditory students or auditory learners. They get score $69,56 \%$, followed kinaesthetic $21,74 \%$, and visual $8,70 \%$. The result showed that, students' auditory learning style is the fastest in learning reading comprehension.

2. There are two learning strategies to facilitate students in learning Contextual Written Language which were developed after analyzed the data, they are inside classroom and outside classroom.

\section{REFERENCES}

Brown, H. Douglas. 2000.Teaching by Principles: An Interactive Approach to Language Pedagogy. Second Edition. White Plains NY: Pearson Education.

Celce Marianne, 2014. Teaching English as a Second or Foreign Language. Marguerita Ann Snow.

Cuaresma, J. (2008). Learning Style Preferences and Academic Performance of PHEM Major at the University of Cordilleras. Unpublished Undergraduate Thesis. University of Cordilleras: Bagiou City.

Dunn and Dunn learning- Style Model Research: Who, What, When, and to What Jamaica, NY: John's University's Centre of the Study of Learning and Teaching Styles.

Fleming, N.D. (2001) Teaching and learning styles: VAK strategies. VAK-Learn: Honolulu

Grenki, J Gost.2000 Impact of Learning- Styles of German Adolescents in Rita Dunn and Shirley

A. Griggs (Eds), Synthesis of the Dunn and Dunn Learning Styles Model Research. Jamaica, NY; St. John's Centre for the Study of Learning and Teaching Styles.

Mackeracher, Dorothy. 2004. Making Sense of Adult Learning, Second Edition, University of Toronto Press. Toronto Buffalo London 